\title{
Attitudes towards Immigrant Workers and Asylum Seekers in Eastern Croatia: Dimensions, Determinants and Differences
}

DOI: $10.11567 /$ met.32.1.4 UDK: 316.64:314.742](497.5-11)"2013" 316.64:341.43](497.5-11)"2013" Izvorni znanstveni rad Primljeno: 21. 12. 2015. Prihvaćeno: 28. 04. 2016.

Margareta Gregurović

Institute for Migration and Ethnic Studies, Zagreb

margareta.gregurovic@imin.hr

Simona Kuti

Institute for Migration and Ethnic Studies, Zagreb

simona.kuti@imin.hr

Drago Župarić-Iljić

Institute for Migration and Ethnic Studies, Zagreb

drago.zuparic@imin.hr

\section{SUMMARY}

Croatia's accession to the EU has brought new challenges and issues in researching and analysing migration flows and trends as well as attitudes and perceptions of real and potential newcomers. The aim of this paper is to explore attitudes of the residents of the two most easterly Croatian counties towards two distinct categories of newcomers: immigrant workers and asylum seekers. The research was conducted shortly after Croatia's entry into the EU, in September 2013, and the presented data are a part of a larger survey that included various migration and ethnicity issues. The survey was applied on a convenience sample of 1110 adult respondents in two counties: Osijek-Baranja and Vukovar-Srijem. Data were analysed in a series of multivariate procedures. Results indicated significant perceptions of immigrant workers within the dimension of cultural threat, along with the expression of a considerable degree of social distance towards them. Asylum seekers were further perceived as a security and economic threat. Within two analysed regression models, the effects on attitudes towards immigrant workers and asylum seekers were similar. Among the spectrum of socio-demographic variables, a statistically significant effect on both dependent variables came from age and political orientation, indicating that older and politically right-oriented respondents expressed more negative attitudes towards both groups. Among other socio-demographic variables, education was significant in predicting attitudes towards immigrant workers, while ethnicity was significant in predicting the attitudes towards asylum seekers. The second model analysed the effect of selected political attitudes and value orientations resulting in significant prediction of negative attitudes towards both groups by pronounced conservativism, support of aggression and submission, social-dominance, dominant submis- 
sive authoritarianism and social alienation, rejecting socially oriented values and expressing greater interest in politics. Differences in prediction of dependent variables indicated that more liberal and better educated respondents had more positive attitudes towards immigrant workers, while Serbs (in comparison to Croats) and respondents rejecting anti-EU orientations had a more positive perception of asylum seekers. The results were compared to other relevant research, including the discussion of observed differences and similarities, and recommendations for further research.

KEY WORDS: immigrant workers, asylum seekers, immigration, attitudes, eastern Croatia

\section{INTRODUCTION}

Croatia's accession to the EU has brought new challenges and issues in researching and analysing migration flows and trends, as well as attitudes and perceptions of immigrants and asylum seekers. Even though the cases of other EU countries showed it was possible to expect increased immigration flows ${ }^{1}$ regardless of the economic situation in a new-member state, current economic conditions in Croatia marked by the global financial crisis shape immigration trends and influence state control over the labour quota system. The result has been a decreasing number of immigrants since 2009 .

On the other hand, by the time of Croatia's accession to the EU, the number of irregular migrants, including asylum seekers, has significantly increased. However, a significant number of asylum seekers leave the country before the first-instance decision (on granting or refusing them refugee status) (Barberić, 2015). This has led to the conclusion that, in the context of an underdeveloped system of integration policies and measures and worsening of economic conditions, Croatia has remained a transit territory for asylum seekers and irregular migrants on their way to Western Europe (Baričević, 2013; Kuti, 2014; Valenta, Zuparic-Iljic and Vidovic, 2015). From mid-September till mid-December 2015, half a million refugees from Syria, Iraq and Afghanistan together with forced migrants from other countries have passed through Croatia, on their way to Germany - the most preferred destination country. ${ }^{2}$

This study, in the broader sense, aims to provide analysis of the perception of two selected groups of migrants (i.e. immigrant workers and asylum seekers) within the specific geographical context of the newly established

\footnotetext{
1 http://ec.europa.eu/eurostat/tgm/table.do?tab=table\&init=1\&language=en\&pco de=tps00176\&plugin $=1$.

2 http://www.mup.hr/219671.aspx.
} 
EU border. Even though the survey was conducted in the period characterised by small numbers of labour migrants and asylum seekers in Croatia, when very few people anticipated a significant increase in the numbers of both groups, the presented study provides specific starting-points having comparable value for further research on this subject. Previous research on Croatian citizens' attitudes towards immigration and its consequences revealed the immigrants being perceived as a synergy of economic, cultural and security threats (Franc, Šakić and Kaliterna-Lipovčan, 2010). According to Šram (2010) the most significant predictors of ethnocentrism are the perception of threat to national cultural identity posed by immigrants, and the perception of threat to national security posed by some ethnic minority groups, mainly Serbs in Croatia. Another research project emphasises that Croatian citizens perceive immigrant workers generally as a socio-economic and socio-cultural threat, expressing a high average social distance towards them (Čačić-Kumpes, Gregurović and Kumpes, 2012).

On the other hand, research on a representative sample of Croatian citizens focusing only on attitudes towards asylum seekers is still lacking. The expert report of the Centre for Peace Studies shows that Croatian citizens do not support declarative discrimination of foreigners; they support multiculturalism and, on average, do not express extreme xenophobic attitudes. However, the study also found a significant level of xenophobia towards certain groups, and a significant proportion of the population feeling that some ethnic, religious and other groups (namely Roma 44\%, Serbs 38\%, Chinese $32 \%$ and Arabs 27\%) pose a threat to Croatia and its citizens. In comparison, $37 \%$ of respondents express xenophobia towards asylum seekers in general (Zastupljenost $i$ indikatori..., 2013: 27). Another study conducted on a student sample indicated the perception of asylum seekers as a social and cultural, as well as health and economic threat (Župarić-Iljić and Gregurović, 2013).-

Along the lines of previous research aimed at exploring attitudes towards and perceptions of specific types of newcomers in Croatia, this research continues to bring forward new information on attitudes and perceptions held on immigrant workers and asylum seekers expressed by the population residing in the two most easterly Croatian counties (Osijek-Baranja and Vukovar-Srijem). Those counties are relevant from several aspects: besides representing the new border area of the EU, they are the Croatian areas most affected by the refugee influx, where transit reception centres are located. These facts could represent the added value of the research, especially in possible "before-after" future comparative research designs. 
Therefore, the main aim of this article is to explore perceptions of immigrant workers and asylum seekers expressed by the residents of eastern Slavonia. To do so, the dimensions and determinants of the attitudes ${ }^{3}$ towards selected groups of newcomers are analysed. The survey data is used to explore the attitudes towards immigrant workers and asylum seekers (within the specific dimensions of social, economic and cultural threat and expressed level of social distance) and to determine possible effects of selected socio-demographic indicators, political attitudes and value orientations on the perceptions regarding the two groups and their potential differences. The research question that served as the starting-point in this study is: are there any differences in perceptions of immigrant workers and asylum seekers in eastern Slavonia, and if there are, what are their (contextual) determinants.

In the first two parts of the article, the authors discuss the definitions and contextual data on analysed groups of newcomers, followed by the theoretical framework of the research and research hypotheses. In the methodology section, the sample, measures and instruments and employed statistical procedures are described. Main results are presented in the following section. The descriptives of dependent variables (attitudes towards immigrant workers and asylum seekers at individual-item level) are analysed, and regression analysis results are presented in two separate models: a) combining the socio-demographic characteristics of respondents and $b$ ) joining the selected political attitudes and value orientations. The final two sections include discussion and conclusions, combined with study limitations and recommendations for future research.

\section{CATEGORIES OF “NEWCOMERS”}

The number of immigrant workers as the first analysed category of newcomers is estimated on the basis of issued residence permits for the purpose of work. Official records for 2013 counted 1371 temporary work permits held by immigrants from the European economic area (EEA), while 2730 temporary work permits were issued to third country nationals (TCNs). According to these numbers, 4101 immigrants with temporary residence permits for the purpose of work made up $12 \%$ of all immigrants in Croatia

In this research, the term "attitudes" is understood in its broader meaning implying different cognitive, conative and emotional components. These components were represented by various items also measuring threat perceptions and social distance. 
in 2013. ${ }^{4}$ According to the data for 2014, the numbers of immigrant workers were even more reduced: 1680 of EEA nationals and 1905 of TCNs, in sum 3585 (10\%) among the total number of 35382 foreigners. ${ }^{5}$ The general number of immigrants with temporary and permanent residence status, hence of labour immigrants as well, has been decreasing steadily. This is also a reflection of a sharp decrease in the labour immigration quotas in Croatia since 2008.

Even though the cases of Central European countries showed that in the first three years after accession to the EU (in 2004 enlargement) there was a noticeable increase in labour immigration flows, this trend does not yet apply to Croatia, since the effects of economic recession have already influenced the reduction of work immigration quotas, and negative net migration in Croatia (Migration of Population of Republic of Croatia, 2014, 2015).

Taking into account historical, especially ex-Yugoslav inter-republic migration patterns, as well as the position of a young EU state, Mežnarić (2014: 182) indicated it is possible to expect that main immigration to Croatia will continue to consist of working immigrants from ex-Yugoslav states, from Eastern Europe (e.g. Ukraine) and some "new member states" (i.e. Romania and Bulgaria). So far, however, there was a significant reduction in the number of immigrants to Croatia in the period from 2008 to $2013^{6}$, as a direct consequence of a reduction in annual quotas for employment of foreigners, which has gradually decreased from 10242 in 2008 to 2329 in 2013.7 In the next period, low economic parameters reflected in the high unemployment rate and reduced quotas could potentially influence decrease in traditionally large immigrant groups, such as citizens of Bosnia-Herzegovina. It is possible to expect they would prefer migrating to the EEA countries rather than competing for relatively low-paid jobs on the highly saturated Croatian labour market. However, statistics show steady numbers in immigration of Bosnia-Herzegovina citizens, as well as small but steady growth in numbers (and the ratio) of EU nationals (especially from Italy, Slovenia and Germany), who immigrated in the period from 2010 (149) to 2014 (2 $334){ }^{8}$

The total number of foreigners in Croatia in 2013 was 33 566, which was less than $1 \%$ of the population. (http://www.mup.hr/main.aspx?id=172024).

5 http://www.mup.hr/main.aspx?id=172024.

6 http://www.dzs.hr/Hrv_Eng/publication/2015/07-01-02_01_2015.htm (table 1)

7 http://narodne-novine.nn.hr/clanci/sluzbeni/2012_12_144_3093.html

8 http://www.dzs.hr/Hrv_Eng/publication/2015/07-01-02_01_2015.htm (table 2) 
The second analysed category of newcomers is the asylum seekers. They were defined in the survey as persons who sought international protection in Croatia due to a well-founded fear of being persecuted because of their race, religion, nationality, membership of a particular social group or political opinions (according to the definition in the 1951 "Convention Relating to the Status of Refugees"). From July 2004 till July 2015, the number of asylum seekers in Croatia has reached 4885 applicants with peaks of 1193 applicants in 2012 and 1089 in 2013. ${ }^{9}$ They largely originate from war-afflicted areas such as Afghanistan, Somalia, Syria or Algeria and Pakistan. However, the number of recognised refugees and/or persons under subsidiary protection remains very low - by July 2015, there were only 165 refugee statuses granted (around 2.5\%) (Statistike, UNHCR, 2015). The term "refugee" refers to a person who is recognized and granted protection status, either as "a refugee (asylee or asylum grantee)" or "a person under subsidiary protection". In the situation of the mass influx of Syrians and other nationals in Europe in 2015, it is important to bear in mind that the research results discussed in this paper refer to attitudes towards asylum seekers, who were present in Croatia up until September 2013.

\section{THEORETICAL FRAMEWORK AND RESEARCH HYPOTHESES}

Research on perceptions of and attitudes towards "newcomers" is a welldeveloped multidisciplinary research-field in the North American, Western European and Australian contexts. There is a partial overlap of attitudinal structures and dimensions in measuring attitudes towards regular (labour) immigrants and foreigners in general, and attitudes towards unauthorised (irregular) migrants - very often including attitudes towards asylum seekers and refugees. Several aspects are common in research of these attitudes: perception of symbolic or real threat posed by newcomers, projected mostly onto the economic stability and cultural identity of the domicile population of the transit or destination country. Various categories of "newcomers" may also be perceived within the dimensions of social, political, security, health and even demographic threat(s).

Existing studies largely focus on testing the socio-economic and cultural hypotheses of attitudes. ${ }^{10}$ In that sense, also having in mind that the aim

9 http://www.unhcr.hr/media/com_form2content/documents/c2/a54/f9/Asylum\%20Total.xls

10 The socio-economic hypothesis is based on the perception of symbolic, real or 
of this article is to explore dimensions and determinants of the attitudes of residents of eastern Slavonia towards immigrant workers and asylum seekers, and to determine differences between attitudes expressed towards both groups, two sets of hypotheses were created based on selected theoretical and contextual standpoints,

The first set refers to different and significant effect of socio-demographic characteristics on both dependent constructs i.e. perception of immigrant workers and asylum seekers. Within the analysis of socio-demographic effects on different attitudes towards migrants, special attention is directed towards socio-economic determinants of respondents and their wider surroundings and questioning of the importance of ethnicity-based determinants of the out- group perceptions.

Previous research analysing the effects of socio-economic determinants mostly deals with the national or comparative multinational level, not focusing on attitudes towards immigrants in different regional and local contexts. However, Markaki and Longhi (2013: 311) point out that "regions with a higher percentage of immigrants born outside the EU and a higher unemployment rate among the immigrant population show a higher probability that natives express negative attitudes to immigration". Even though the percent of TCNs residing in the two eastern Croatian counties analysed in this paper is not significant, a large proportion of the overall national minority population is living there in post-conflict multi-ethnic local communities.

Moreover, these counties continuously register the highest rates of unemployment in the country, creating a macro socio-economic context for possible competition on an individual and group level, over scarce resources such as jobs. Ethnic Competition Theory, as devised by Scheepers, Gijsberts and Coenders (2002: 18), explains the potential outcomes of competition on an individual and contextual level, which can lead to ethnic exclusionism, ${ }^{11}$

integrated threat that newcomers pose to the economic stability of the domicile population, while the cultural hypothesis is based on the perception of sociocultural threats that "come from" immigrants, asylum seekers and refugees through perceived conflicting values (Ervasti, 2004; Schneider, 2008).

11 This theory derives from two complementary paradigms - Realistic Conflict Theory and Social Identity Theory. The first one relates to Blalock's (1967, in Scheepers, Gijsberts and Coenders, 2002: 18) distinction of actual and perceived competition. Socio-economic conditions on macro- and meso-levels are related to the actual competition over available resources, while on the micro-level it refers to individual competition between different ethnic group(s) members in their pursuit of better socio-economic positions within the labour market. These 
i.e. it explains how the members of majority (dominant group) could develop attitudes/perceptions of hostility towards out-groups. Theory also suggests that "natives" would have to compete with newcomers for the scarce resources (e.g. employment), therefore having stronger negative attitudes towards immigrants (Semyonov, Raijman and Gorodzeisky, 2006; PardosPrado, 2011). Even though some research resulted in the quite surprising finding that "a higher regional unemployment rate of natives is associated with lower feelings of threat from immigration", as suggested by Markaki and Longhi (2013: 314), ${ }^{12}$ the first hypothesis of this research is aligned with ethnic competition theory:

H1 - a stronger effect on attitudes towards immigrant workers is expected by indicators of the socio-economic status and employment status of respondents, meaning that negative perception of immigrant workers is expected to be more pronounced among the respondents with lower socio-economic status and unemployed respondents, since immigrant workers are more often researched within the economic context in contrast to asylum seekers.

In addition, within the analysis of socio-economic context, we consider the dynamic intergroup conflict theory (Meuleman, Davidov and Billiet, 2009) according to which the shift towards more negative attitudes on immigration (measured in 17 European countries for the 2002-2007 period) occurred due to various migration flow changes and dynamics in the unemployment rates of the local population in the host countries. Similarly, Pardos-Prado (2011) suggests that, in the situation of national economic decline, along with high levels of individual socio-economic vulnerability, negative attitudes toward immigrants may be explained by out-group economic competition theory (together with other individual and contextual variables). Finally, Raijman (2010: 91) describes the concept of "competitive threat" that an

conditions might in return influence the subjective perception of competitiveness, and the threat that comes from ethnic out-group members. Social Identity Theory refers to positive social-identification with in-group and negative evaluation of out-groups through social contra-identification. The outcome of this process on the individual and contextual (macro) level Scheepers, Gijsberts and Coenders (2002: 19) term as Ethnic Exclusionism, and conclude "actual competitive conditions might reinforce the process of social (contra-) identification, which may induce more widespread support for ethnic exclusionism".

12 Rustenbach (2010: 68) also discussed how such a positive correlation could usually be the result of looking at immigrants as the new "spenders" and new workers on the lowest-skilled job occupations, which both may boost the local economy. 
individual can express towards newcomers who are perceived as competitors for different, mainly economic and social, resources and advantages, opportunities and services (see also Banovac and Boneta, 2006; Murray and Marx, 2013; Strabac, Aalberg and Valenta, 2014).

Furthermore, in accordance with the cultural hypothesis, the attitudes towards different categories of foreigners are sometimes related to perceived threat connected with their ethnic, cultural and/or religious background. In cross-national research conducted in the USA, the UK, Norway and Sweden in 2009, Strabac, Aalberg and Valenta (2014) found that antiMuslim attitudes are shaped by the same individual traits that influence general xenophobia, even though the results indicate that when it comes to the racial/ethnic and religious/cultural background of immigrant population, Muslim immigrants were not perceived more negatively than immigrants in general.

However, in the specific Croatian context, societal integration and interpersonal trust between the national majority and national minority was significantly lowered due to war atrocities and post-conflict antagonisms, while the (inter)ethnic distance has risen (cf. Banovac and Boneta, 2006). Croatian Serbs sometimes represent the majority in distinct municipalities of two Eastern Slavonia counties. ${ }^{13}$ They experienced war-induced displacement and exile, followed by post-conflict return and reintegration, similarly to their Croatian neighbours within the same region (Mesić and Bagić, 2011). Even though Mayda (2004: 23) concludes in her research that individual belonging to the domicile ethnic majority ("dominant ethnic group") has insignificant impact on attitudes toward foreigners, Crawley, Drinkwater and Kauser (2013: 19) indicate, on the UK example, that ethnic minority groups tend to have a more positive opinion on refugees. According to these results, also bearing in mind the specificities of the Croatian context and minority refugee experience, the second hypothesis of this paper is:

$\mathrm{H} 2$ - a stronger effect on attitudes towards asylum seekers is expected by the indicator of ethnicity of respondents, meaning that a negative perception of asylum seekers is expected to be less pronounced among national minority (Serb) respondents.

Nevertheless, besides economic, geographical and ethnicity-based factors, other socio-demographic and contextual variables may have a significant effect on the attitudes (especially gender and interpersonal social contact).

13 On the national level, Serbs represent the largest ethnic group with national minority status. 
In South-East European countries, only a few studies have researched the attitudes towards diverse categories of immigrants. Zavratnik (2012: 204) shows that immigrants in Slovenia are perceived as "a factor of unfair competition for the domestic population and a burden for the taxpayers". Furthermore, "the public opinion favours segmented admission of immigrants, based on both geographical origin and socio-economic background", and finds "as the most important for [immigrants'] successful integration in Slovene society: knowledge of the language, adequate education and employment" (Zavratnik, 2012: 204). Nonchev, Encheva and Atanassov (2012) discuss the attitudes towards immigrants by looking at the variations in respondents' individual characteristics and structural preconditions within the Bulgarian national context in comparison to the attitudes towards immigrants in the EU. They conclude that older, less educated, poorer and ethnic Bulgarians tend to be more intolerant in general, regardless of the fact of the very low numbers of foreigners residing in Bulgaria, which also applies in the Croatian context leading to the next hypothesis referring to the effects of socio-demographic characteristics:

$\mathrm{H} 3$ - negative perception of both groups of newcomers (immigrant workers and asylum seekers) is expected to be more pronounced in males, older respondents, lower educated, politically right oriented, non-religious persons.

The second set of assumptions dealt with in this research refers to the effect of different value orientations and political attitudes towards both dependent constructs - attitudes towards immigrant workers and asylum seekers.

As pointed out in numerous studies (e.g. Semyonov, Raijman and Gorodzeisky, 2006; Zick, Pettigrew and Wagner, 2008; Cohrs and Stelzl, 2010), negative attitudes towards out-group members can be explained using the Theory of Right-Wing Authoritarianism (RWA, Altemeyer, 2006), which is very context-dependent, similarly to Social-Dominance Orientation Theory (SDO, cf. Pratto et al., 1994). According to Cohrs and Stelzl (2010: 688-689), in countries such as Germany or Italy, where immigrants are perceived as a security threat increasing crime rates, and as an economic threat (decreasing economic advancement), RWA is a particularly high predictor of antiimmigrant attitudes. On the other hand, SDO was a particularly high predictor of anti-immigrant attitudes in countries such as Belgium or Sweden, where immigrants are "economically disadvantaged" (with higher rates of unemployment in comparison to the domicile population) and generally 
"lower in socio-economic status". Moreover, the characteristics of higher conservativism and lower liberalism (occasionally accompanied by highly pronounced anti-Western or anti-EU orientation /Šram, 2001/) could also indicate a higher level of negative perception of any out-group including the immigrants and asylum seekers (see for instance Mehrabian, 1996; Espenshade and Hempstead, 1996; Scheepers, Gijsberts and Coenders, 2002; Čačić-Kumpes, Gregurović and Kumpes, 2014).

Finally, the analyses in this paper were also correspondent with Rustenbach's (2010) test of different explanation types of anti-immigrant attitudes. Putting "societal integration" at the top, she stressed that "individual and regional interpersonal trust were the strongest predictors of anti-immigrant attitudes" (Rustenbach, 2010: 67). According to that explanation, out-group cultural characteristic (language, customs, values) pose uncertainty and threat in domicile-immigrant relations. Furthermore, "living in regions where interpersonal trust is high may create a positive context of reception toward immigrants where, as a whole, they are perceived more positively which would, in turn, influence an individual towards a more positive view" (Rustenbach, 2010: 67).

The results and conclusions, demonstrated in many other studies, (e.g. Pratto et al., 1994; Mehrabian, 1996; Bardy and Schwartz, 2003; Altemeyer, 2006; and Pardos-Prado, 2011) served as the basis for the final hypothesis:

$\mathrm{H} 4$ - negative perception of both groups of newcomers (immigrant workers and asylum seekers) is expected to be more pronounced in more conservative, less liberal, more authoritarian, more closed towards the EU, more socially alienated respondents with lower attachment to socially oriented values, and in respondents who have less interest in politics.

\section{METHODOLOGY}

\section{Sample}

The data were gathered in September 2013 as part of a wider survey aimed at exploring interethnic relations in eastern Croatia. The survey was conducted on a convenience sample $(\mathrm{N}=1110)$ in order to evaluate the specific issues of ethnic attitudes, political behaviour, values and personality traits on proportional and otherwise similar samples of Croats and Serbs in the two most eastern Croatian counties: Osijek-Baranja and VukovarSrijem. 
The reasons for selecting those two counties were multiple: both counties were significantly affected by the war in Croatia, with deterioration of basic human capital and trust within the divided multi-ethnic local communities. Taking into account that the analysed sample evenly represents members of the ethnic majority and the largest Croatian ethnic minority (formerly in conflict), it is possible to expect low levels of interpersonal trust in these counties (even towards the members of "in-groups"14), also resulting in more negative attitudes of "locals" towards the out-group members, i.e. "newcomers". A second reason is related to the humanitarian crisis and influx of refugees and other irregular migrants since 2015 in which these two counties represent the borderline i.e. the place of entry into Croatia. This fact probably (significantly) modifies the perceptions of the local population towards these groups of newcomers, creating the future research basis for "before-after" comparisons.

Table 1 shows the main characteristics of sampled respondents including age, gender, educational level, ethnicity as well as self-estimated socioeconomic status, reported political orientation and religious self-identification. ${ }^{15}$

14 In this context, we also consider the members of ethnic minorities as members of in-groups, since they have been an integral part of the analysed population for years, so the analyses were carried out on a joint sample of both Croats and Serbs, making no significant difference between them.

15 This research deals with the convenience sample so it is important to compare it to the general population of the two selected counties due to possible implications for the interpretations of the results. The available data from the Croatian Bureau of Statistics $(2013,2014)$ imply minor deviation in the sample regarding age structure (the oldest respondents are under-represented by $10 \%$ in favour of the 31-45 age category). Gender structure completely matches the population. Education structure, however, is significantly deviated, resulting in overrepresentation of the highly educated by $20 \%$ and respondents with completed secondary school by $10 \%$, resulting in under-representation of respondents with the lowest education level. The share of unemployed is by $3 \%$ higher in the sample. Finally, the data on ethnic composition indicating that even though the proportion of Serbs in the selected counties (7.8\% in Osijek-Baranja and $15.5 \%$ in Vukovar-Srijem County) exceeds the overall proportion in Croatia (4.4\%), it is still much higher in our sample. 
Table 1. Sample descriptives

\begin{tabular}{|c|c|c|c|}
\hline Variable & Categories & $\mathbf{N}$ & $\%$ \\
\hline \multirow{2}{*}{ Gender } & Male & 513 & 46.3 \\
\hline & Female & 595 & 53.7 \\
\hline \multirow{4}{*}{ Age } & 30 or lower & 277 & 25.0 \\
\hline & $31-45$ & 348 & 31.4 \\
\hline & $46-60$ & 299 & 27.0 \\
\hline & 60 or older & 185 & 16.7 \\
\hline \multirow{3}{*}{ Education } & Primary education or lower & 104 & 9.4 \\
\hline & Secondary education & 659 & 59.6 \\
\hline & Faculty/tertiary vocational school or higher & 342 & 30.9 \\
\hline \multirow{3}{*}{ SES } & Lower than the majority & 201 & 18.3 \\
\hline & Neither better nor worse than the majority & 702 & 63.8 \\
\hline & Better than the majority & 198 & 18.0 \\
\hline \multirow{3}{*}{$\begin{array}{l}\text { Employment } \\
\text { status }\end{array}$} & Employed & 529 & 47.91 \\
\hline & Unemployed & 193 & 17.5 \\
\hline & Other (retired, students, housewives) & 383 & 34.7 \\
\hline \multirow{2}{*}{ Ethnicity } & Croatian & 560 & 50.5 \\
\hline & Serbian & 550 & 49.5 \\
\hline \multirow{5}{*}{$\begin{array}{l}\text { Political } \\
\text { orientation }\end{array}$} & Left & 229 & 22.2 \\
\hline & Left centre & 130 & 12.6 \\
\hline & Centre & 394 & 38.2 \\
\hline & Right centre & 163 & 15.8 \\
\hline & Right & 115 & 11.2 \\
\hline \multirow{6}{*}{$\begin{array}{l}\text { Religious self- } \\
\text { perception }\end{array}$} & Not religious - against religion & 26 & 2.4 \\
\hline & Not religious - has nothing against religion & 132 & 12.1 \\
\hline & Indifferent & 76 & 7.0 \\
\hline & Uncertain & 97 & 8.9 \\
\hline & Religious & 298 & 27.4 \\
\hline & Convinced believer & 459 & 42.2 \\
\hline
\end{tabular}


The proportion of female respondents exceeds the proportion of males by almost $8 \%$. The respondents are relatively evenly distributed in the first three age categories, while the oldest respondents participated in the survey in the smallest proportion. The mean age of the whole sample is 44 years. Since the operationalisation of the research targeted both the ethnic majority, and Croatia's largest ethnic minority - the Serbs, the two ethnic groups are equally represented in the sample. Most of the respondents had completed secondary education (60\%) as the highest level of education, and most of the respondents estimated their own socio-economic status as being no different than that of the majorities (64\%). Finally, most of the respondents position themselves at the political centre, even though the distribution is leaning towards the left. On the other hand, the majority of respondents declare themselves as being religious or convinced believers (in total 70\%).

\section{Measures}

Two scales were used as dependent indicators in the analyses. Perception of immigrant workers consists of five items and measures attitudes towards immigrant workers mostly within the categories of cultural threat and perceived social distance (cf. Halperin, Canetti-Nissim and Pedahzur, 2007). The second dependent indicator is the Perception of asylum seekers, consisting of six items measuring the level of economic and security threat posed by asylum seekers, but also the perception of their cultural influence (cf. Župarić-Iljić and Gregurović, 2013). In assessing the statements of both scales, the respondents used a 5-point Likert Scale (from 1 - "Strongly disagree" to 5 - "Strongly agree"). Higher result on the scales indicated a more negative perception of both groups.

Aside from the described socio-demographic variables, ten indicators were used in analyses in order to explore their effects on dependent indicators: 1) Conservativism (3 items) presented by attitudes such as giving support to conservative political parties and rejection of communism or national media for being "too left-wing" (cf. Mehrabian, 1996); 2) Liberalism (4 items) represented by support to left-wing political parties and giving preference to socialism over capitalism (cf. Mehrabian, 1996); 3) Anti-EU Orientation (5 items) indicated that the EU would ruin all aspects of a national state, such as its sovereignty, natural wealth, national identity and would turn it into its colony (cf. Šram, 2001); 4) Right-wing Authoritarianism - Aggression and Submission dimension (9 items) indicating that the only possible path to a prosperous society is through respecting traditional values and strong authorities and leaders, even at cost of "destroying trouble-makers 
and other immoral people" (cf. Altemeyer, 2006); 5) Dominant-submissive Authoritarianism (8 items) represented by support to respecting authorities, requesting obedience and punishing law-breakers and delinquents; 6) Social-Dominance Orientation (14 items) included at the general factor level indicating support to social hierarchy, domination over lower status groups and countering social equality (cf. Pratto et al., 1994); 7) Socially oriented values (5 items) factor derived from Schwartz's 10 value domains presented by higher evaluation of benevolence, security, universalism, tradition and conformity (cf. Bardy and Schwartz, 2003); 8) Individually oriented values (5 items) factor derived from Schwartz's 10 value domains presented by higher evaluation of stimulation, achievement, hedonism, power and self-direction (cf. Bardy and Schwartz, 2003); 9) Social Alienation (12 items) included at the general factor level indicating perception of interpersonal distrust and anomy, hopelessness and helplessness in society (cf. Šram, 2009); 10) Interest in politics (5 items) measured by incidence of reading newspaper articles, discussing politics with friends and family members, and following TV and radio programmes dealing with politics (cf. Šram, 2009).

A 5-point Likert Scale was used to determine the level of respondents' agreement with each item (from 1 - "Strongly disagree" to 5 - "Strongly agree").${ }^{16}$ Higher results on all analysed scales refer to greater support and agreement with the measured constructs. ${ }^{17}$

\section{Statistical procedures}

Confirmatory factor analysis (CFA) was conducted first in order to check the dimensionality of dependent constructs. ${ }^{18}$ Frequency distributions of

16 In assessing the 10 value domains, respondents were using the answer scale from 1 - "Not important at all" to 5 - "Extremely important".

17 All independent indicators were previously validated in cited research as the measurements of different attitudinal spaces. Even though it might seem that selected indicators share the same subject area, and the Thurston principle of the simple structure defines that the variable is a good indicator in case its saturations on other dimensions are extremely low, Culig (2005: 225) stresses that "when it comes to political attitudes, values, interests and similar subjects, the variables are by their nature multifaceted so these criteria do not have to be so strictly obeyed if the content of factor is consistent". Further, in order to monitor the possible effect of inter-correlations of independent variables, special attention was given to suppression (monitoring discrepancies between beta coefficients, partial and zero-order correlations) and a multi-collinearity check (tolerance and the VIF coefficient) in regression analyses.

18 In conducting the CFA, the Maximum Likelihood Estimation Method was used and model fit was assessed on several indices: significance of $\chi^{2}(p$-value should 
attitudes expressed towards immigrant workers and asylum seekers were then analysed. Latent constructs of these attitudes were analysed using exploratory factor analysis (EFA) (Principal component method, GK criterion of factor extraction and Varimax rotation). ${ }^{19}$ The results of the factor analysis served as a basis for construction of two dependent composite variables, which were further used as criterion variables in two models of multiple regression analysis. Regression analyses ${ }^{20}$ were conducted in order to determine specific characteristics of respondents prone to expressing positive or negative attitudes towards immigrant workers and asylum seekers. Hierarchical regression analysis was conducted, introducing in the first step the indicators of socio-demographic variables as predictors (presented in Table 1) and ten indicators presenting the specific political attitudes and value orientations of respondents as predictors in the second step. ${ }^{21}$ All indicators were included in regression analysis as factor scores. ${ }^{22}$

\section{RESULTS}

\section{Attitudes towards immigrant workers and asylum seekers}

Prior to further analyses, the dimensionality of two dependent constructs was checked. CFA confirmed the existence of two separate dimensions: firstly measuring attitudes towards immigrant workers and secondly the attitudes towards asylum seekers. Even though the constructs comprise items exploring different dimensions of attitudes, threat perception and social distance, satisfactory fit statistics of the obtained model indicates that

not be significant /rarely obtained/), RMSEA (<0.08), CFI (value close to 1.00) and NNFI (value close to 1.00) (for more on fit indices criteria see Gregurović, 2014: 94-95).

19 Varimax rotation was used to obtain independent dimensions of certain valueattitude space and to avoid possible suppression in multiple regression (Čulig, 2005: 224).

20 The Enter Method of Regression Analysis was used to enable better comparability of the effect on two dependent variables.

${ }^{21}$ Aside suppression and multi-collinearity check CFA was conducted in order to test the possible overlapping of constructs entering the regression. Even though marginally acceptable (cf. Hair et al., 2010), fit measures of conducted CFA $\left(\chi^{2}=16316.03 ; \mathrm{df}=2300 ; \mathrm{p}=0.00 ; \mathrm{RMSEA}=0.074 ; \mathrm{CFI}=0.90 ; \mathrm{NNFI}=0.90\right)$ enabled us to treat the selected constructs as independent indicators.

22 EFA was used to enable clarity and comprehensiveness of the selected scales (which were further included in regression analysis), also by using the Principal Component Method, GK criterion of factor extraction and Varimax rotation. 
the expected indicators create consistent dimensions. ${ }^{23}$

Table 2 presents frequency distributions of attitudes towards immigrant workers in Croatia. Data show that the respondents do not agree in the highest proportions with these statements, even though the mean values indicate indecision. These results imply that immigrant workers are not perceived as a cultural threat or as a threat to values of the host society. Additionally, in the largest proportions, respondents could accept immigrant workers as their neighbours, guests or even as bosses at work. EFA resulted in a single latent construct representing all statements with good internal consistency (Cronbach's Alpha $=0.908) .{ }^{24}$

Table 2. Frequencies of the attitudes towards immigrant workers (\%)

\begin{tabular}{|c|c|c|c|c|c|c|c|c|c|}
\hline & 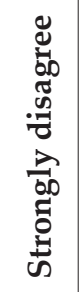 & 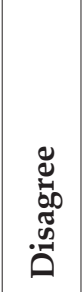 & 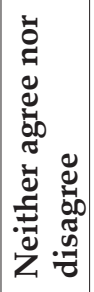 & 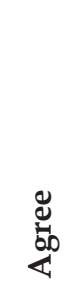 & 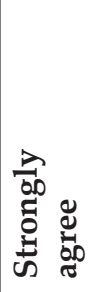 & $\stackrel{\infty}{\sum}$ & $\mathbf{M}$ & SD & 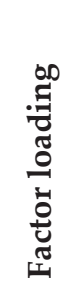 \\
\hline $\begin{array}{l}\text { 1. A high proportion of } \\
\text { migrant workers will } \\
\text { endanger our culture and } \\
\text { tradition. }\end{array}$ & 32.3 & 19.6 & 25.6 & 11.9 & 9.9 & 0.6 & 2.47 & 1.319 & .787 \\
\hline $\begin{array}{l}\text { 2. I wouldn't like to live in } \\
\text { the same neighbourhood } \\
\text { with migrant workers. }\end{array}$ & 25.9 & 18.3 & 32.6 & 13.7 & 8.7 & 0.7 & 2.61 & 1.252 & .892 \\
\hline $\begin{array}{l}\text { 3. It would be very hard } \\
\text { for me to accept a migrant } \\
\text { worker as my boss. }\end{array}$ & 24.7 & 17.4 & 30.2 & 13.1 & 13.7 & 1.0 & 2.73 & 1.338 & .872 \\
\hline $\begin{array}{l}\text { 4. I would hardly ever } \\
\text { invite a migrant worker to } \\
\text { be a guest in my home. }\end{array}$ & 28.9 & 19.5 & 31.1 & 10.5 & 9.3 & 0.8 & 2.51 & 1.267 & .865 \\
\hline $\begin{array}{l}\text { 5. Migrant workers will } \\
\text { never adopt our society's } \\
\text { values and way of life. }\end{array}$ & 21.4 & 19.7 & 34.7 & 12.6 & 10.9 & 0.7 & 2.72 & 1.244 & .863 \\
\hline
\end{tabular}

$23 \quad \chi^{2}=313.46 ; \mathrm{df}=43 ; \mathrm{p}=0.00 ; \mathrm{RMSEA}=0.076 ; \mathrm{CFI}=0.98 ; \mathrm{NNFI}=0.98$.

24 The preconditions for conducting factor analysis have been met: significant at 0.001 level KMO was 0.877 and Bartlett's Test was 3568.789; a low proportion of high correlations in the anti-image correlation matrix. The factor explained $73.37 \%$ of scale variance. 
When it comes to attitudes towards asylum seekers (Table 3), respondents hesitate to a greater extent. Both average responses and frequency distributions indicate that respondents cannot decide whether asylum seekers represent an economic threat (as a burden for the taxpayers and in a form of real estate prices' decline) and a security threat in a local community. On the other hand, asylum seekers are in a larger proportion rejected as a political threat and as a threat for the overall economic development of Croatia. Most of the respondents were also indifferent regarding the possible influences of asylum seekers' culture, even though the distribution was leaning towards disagreement with Croatian "cultural exclusivity". Again, applied EFA resulted in a single factor solution with high internal consistency (Cronbach's Alpha $=0.889) .{ }^{25}$

Table 3. Frequencies of the attitudes towards asylum seekers (\%)

\begin{tabular}{|c|c|c|c|c|c|c|c|c|c|}
\hline & 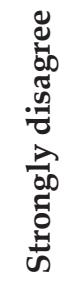 & 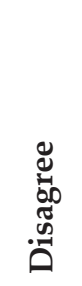 & 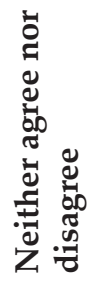 & 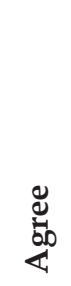 & 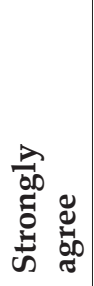 & $\stackrel{\infty}{i}$ & $\mathbf{M}$ & SD & 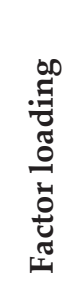 \\
\hline $\begin{array}{l}\text { 1. Asylum seekers } \\
\text { represent a burden for the } \\
\text { taxpayers. }\end{array}$ & 13.5 & 13.6 & 37.0 & 21.3 & 13.9 & 0.7 & 3.08 & 1.204 & .795 \\
\hline $\begin{array}{l}\text { 2. Asylum seekers pose a } \\
\text { security threat in the local } \\
\text { community where they } \\
\text { are present. }\end{array}$ & 17.0 & 17.3 & 39.7 & 16.3 & 8.6 & 1.0 & 2.82 & 1.160 & .856 \\
\hline $\begin{array}{l}\text { 3. Asylum seekers' culture } \\
\text { should not interfere with } \\
\text { Croatian culture. }\end{array}$ & 18.9 & 15.9 & 35.0 & 16.8 & 12.5 & 0.9 & 2.88 & 1.260 & .768 \\
\hline $\begin{array}{l}\text { 4. Shelter for asylum } \\
\text { seekers causes decline of } \\
\text { real estate prices in the } \\
\text { immediate vicinity. }\end{array}$ & 18.4 & 14.0 & 43.4 & 15.2 & 8.4 & 0.6 & 2.81 & 1.156 & .780 \\
\hline
\end{tabular}

25 The original scale was composed of nine items. Three were dropped due to inadequate distributions and/or low discriminatory power. The preconditions for conducting factor analysis have been met: significant at 0.001 level KMO was 0.887 and Bartlett's Test was 3367.387; low proportion of high correlations in the anti-image correlation matrix. The factor explained $64.57 \%$ of scale variance. 


\begin{tabular}{|c|c|c|c|c|c|c|c|c|c|}
\hline & 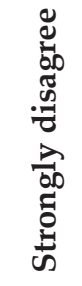 & 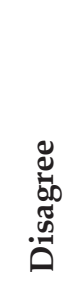 & 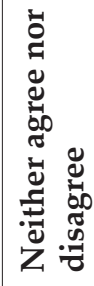 & $\frac{\Xi}{\square}$ & 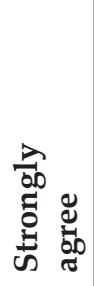 & $\stackrel{\mathscr{W}}{\Sigma}$ & $\mathbf{M}$ & SD & \\
\hline $\begin{array}{l}\text { 5. Asylum seekers } \\
\text { jeopardize the stability of } \\
\text { Croatian political order. }\end{array}$ & 27.7 & 21.4 & 35.9 & 8.6 & 5.5 & 0.8 & 2.42 & 1.145 & .799 \\
\hline $\begin{array}{l}\text { 6. Asylum seekers are a } \\
\text { burden for the economic } \\
\text { development of our } \\
\text { country. }\end{array}$ & 20.6 & 17.8 & 34.9 & 15.7 & 10.2 & 0.8 & 2.77 & 1.236 & .820 \\
\hline
\end{tabular}

Based on factor analyses results, the indicators of perceptions of immigrant workers and asylum seekers were recalculated into composite variables, which were used in further analyses. ${ }^{26}$ Since the items measuring attitudes towards immigrant workers and asylum seekers are not compatible, i.e. they are targeting different dimensions of attitudes and threat perceptions, they cannot be directly compared. However, the correlation between the two constructs is moderately high and positive $(\mathrm{r}=0.607 ; \mathrm{p}=0.000)$ indicating that respondents who express negative attitudes towards immigrant workers also express negative attitudes towards asylum seekers. Both of these variables are further analysed as dependent (criterion variables) in regression analyses.

\section{Effects of socio-demographic characteristics, political attitudes and value orientations on attitudes towards immigrant workers and asylum seekers}

Using hierarchical regression analysis, two sets of predictors were introduced representing different characteristics of respondents in prediction of positive or negative attitudes towards immigrant workers and asylum seekers.

Even though it was possible to presume the significance of socio-demographic characteristics in prediction of perceptions of immigrant workers and asylum seekers, Model 1 explains around $4-5 \%$ of variance of both dependent variables (Table 4).

26 Distributions of both composite variables are normal and higher results indicate more negative perception of both groups. 
Table 4. Regression analysis - the effect of socio-demographic characteristics, political attitudes and value orientations on perception of immigrant workers and asylum seekers

\begin{tabular}{|c|c|c|c|c|}
\hline & \multicolumn{2}{|c|}{$\begin{array}{l}\text { Negative perception of } \\
\text { immigrant workers }\end{array}$} & \multicolumn{2}{|c|}{$\begin{array}{l}\text { Negative perception } \\
\text { of asylum seekers }\end{array}$} \\
\hline & Model 1 & Model 2 & Model 1 & Model 2 \\
\hline Gender (female) & -.025 & .003 & -.028 & .004 \\
\hline Age & $.075^{*}$ & $.071^{*}$ & $.107^{* *}$ & $.083^{*}$ \\
\hline Ethnicity (Serbian) & -.029 & .001 & $-.076^{*}$ & $-.092 *$ \\
\hline Education & $-.100^{* *}$ & -.026 & -.053 & .018 \\
\hline Self-estimated SES & -.003 & .026 & -.045 & -.007 \\
\hline $\begin{array}{l}\text { Employment status } \\
\text { (unemployed) }\end{array}$ & .025 & .018 & .012 & .006 \\
\hline Political orientation & $.097^{*}$ & -.071 & $.116^{* *}$ & .026 \\
\hline Religious self-perception & .066 & .019 & .039 & .004 \\
\hline Conservativism & & $.277^{* * *}$ & & $.169 * * *$ \\
\hline Liberalism & & $-.119 * *$ & & -.017 \\
\hline Anti-EU & & .050 & & $.136^{* * *}$ \\
\hline $\begin{array}{l}\text { RWA F1 - Aggression and } \\
\text { submission }\end{array}$ & & $.152^{* *}$ & & $.113^{*}$ \\
\hline $\begin{array}{l}\text { Dominant-submissive } \\
\text { Authoritarianism }\end{array}$ & & $.092 *$ & & $.216^{* * *}$ \\
\hline $\begin{array}{l}\text { Social Dominance } \\
\text { Orientation (GF) }\end{array}$ & & $.093^{* *}$ & & $.089^{* *}$ \\
\hline $\begin{array}{l}\text { Schwartz Values (F1) - } \\
\text { "socially oriented" }\end{array}$ & & $-.106^{* *}$ & & $-.102 * *$ \\
\hline $\begin{array}{l}\text { Schwartz Values (F2) - } \\
\text { "individually oriented" }\end{array}$ & & .009 & & -.004 \\
\hline Social Alienation (GF) & & $.156^{* * *}$ & & $.084^{*}$ \\
\hline \multirow[t]{2}{*}{ Interest in politics } & & $.087^{* *}$ & & $.106^{* *}$ \\
\hline & $\begin{array}{l}F=4.264 \\
p=0.000 \\
\mathbf{R}^{2}=\mathbf{0 . 0 3 8}\end{array}$ & $\begin{array}{c}\mathrm{F}=15.004 \\
\mathrm{p}=0.000 \\
\mathbf{R}^{2}=\mathbf{0 . 2 3 9} \\
\Delta \mathrm{R}^{2}=.201^{* * *}\end{array}$ & $\begin{array}{l}F=5.265 \\
p=0.000 \\
R^{2}=\mathbf{0 . 0 4 6}\end{array}$ & $\begin{array}{c}\mathrm{F}=16.856, \\
\mathrm{p}=0.000 \\
\mathbf{R}^{2}=\mathbf{0 . 2 6 0} \\
\Delta \mathrm{R}^{2}=.214^{* * *}\end{array}$ \\
\hline
\end{tabular}


Differences between the effects on two dependent variables are visible. Out of seven predictors, two variables had a significant effect on both the perception of immigrant workers and asylum seekers: political orientation as the strongest predictor of perception of both groups and age. Each model also had a specific single statistically significant predictor. In the case of the perception of immigrant workers, it was education and in the case of perception of asylum seekers, a significant effect was the ethnicity of respondents. The results show that older respondents and those who place themselves more towards the right of the political spectrum express more negative attitudes towards both target groups and perceive them as a greater threat. On the other hand, respondents with lower education levels express more negative attitudes towards immigrant workers, while Serbs express more positive attitudes towards asylum seekers than Croats. The implications and interpretations of the results are discussed below.

Since the socio-demographic characteristics explain relatively low variance percentage, the effects of a wider range of respondents' values and political attitudes on their perception of immigrant workers and asylum seekers were tested in the second model. This resulted in a statistically significant increase of explained variance of both dependent constructs.

The second model explains slightly more variance of the perception of asylum seekers $-26 \%$ as opposed to $24 \%$ of variance of the perception of immigrant workers. Seven statistically significant predictors are common to both dependent variables. Conservativism has the strongest effect on both variables indicating that more conservative respondents perceive immigrant workers and asylum seekers more negatively. Further, the respondents with high scores on aggression and submission scales, those who support dominant-submissive authoritarianism and social dominance, respondents who are socially alienated, who have greater interest in politics and support less socially oriented values, have more negative attitudes towards both groups.

There are also some differences between the two models: from a significant effect of liberalism on more positive attitudes towards immigrant workers, and a significant effect of anti-EU orientation when it comes to more negative attitudes towards asylum seekers. The political attitudes included in the second model expectedly suppressed the effect of political orientation, due to high inter-correlation and overlapping in the ideological background of the two constructs.

Nevertheless, the results generally show that there are few significant differences in expressing attitudes towards immigrant workers and asylum 
seekers, which leads to the conclusion that both groups are perceived as "different" or "others", and not recognised as disparate categories of "newcomers".

\section{DISCUSSION}

The aim was to explore the dimensions and determinants of perceptions and attitudes of residents of eastern Slavonia towards immigrant workers and asylum seekers, and to determine differences in expressed attitudes towards both groups. In comparison to previous research in Croatia, the results might indicate more positive attitudes towards immigrant workers. For example, Čačić-Kumpes, Gregurović and Kumpes (2012) in the research of attitudes toward foreign workers on a representative sample of Croatian citizens, report on an overall exclusionary attitude of Croatian citizens towards the (potential) arrival of immigrant workers. However, since our research included a convenience sample of respondents in eastern Croatia, it is impossible to generalise the findings and assume their transferability to other parts of Croatia. On the other hand, in a study on a convenience sample of Zagreb University students, Župarić-Iljić and Gregurović (2013) found that asylum seekers are perceived as a social, cultural and (particularly) as a health and economic threat to a significant degree. However, since that study targeted the student population in Zagreb, it is impossible to reach any comparable conclusions on attitudes towards asylum seekers and their possible trends.

Two groups of newcomers are assessed within different dimensions of attitudes and threat perceptions in this research, which prevents direct comparisons between the two constructs. However, conducted analyses provide an insight into possible determinants of the perceptions related to both groups. These perceptions are analysed as composite indicators, which combine items assessing attitudes, threat perceptions and social distance towards immigrant workers and asylum seekers.

It was hypothesised that different socio-demographic characteristics would have a significant effect on both dependent constructs. Even though not all socio-demographic predictors had a significant effect on perceptions of both groups, the results indicated that older respondents express more negative attitudes towards both immigrant workers and asylum seekers, while the respondents with lower education levels express more negative attitudes towards immigrant workers. This finding is consistent with the often replicated result in various research contexts, which indicates that 
younger and more educated respondents are more tolerant and open towards different types of diversity and have a lower tendency overall to express ethnic prejudice (Chandler and Tsai, 2001; Hello, Scheepers and Gijberts, 2002; Nonchev, Encheva and Atanassov, 2012). However, it is important to keep in mind the possible influence of an "over-educated" sample. The other statistically significant predictor in both models is political orientation. Respondents who place themselves more towards the right of the political spectrum express more negative attitudes towards both target groups and perceive them as a greater threat. This finding is also consistent with other research (Rustenbach, 2010; Pardos-Prado, 2011; Scheepers, Gijsberts and Coenders, 2002; Semyonov, Raijman and Gorodzeisky, 2008) and can be explained within the theory of right-wing authoritarianism, to which tendencies are ascribed to expressing prejudice and negative attitudes toward "out-groups" to motivational interests connected to group cohesion, stability and security (Altemeyer, 2006).

The hypothesis that a stronger effect on attitudes towards immigrant workers is expected by the indicators of the socio-economic status and employment status of respondents has not been confirmed by regression analysis, since the effect of employment status and self-estimated SES was not statistically significant in prediction of either of the dependent variables.

On the other hand, the assumed effect of ethnicity was confirmed to a certain extent. Even though the authors predicted a significant effect on both dependent variables, simultaneously expecting a stronger effect on perceptions of asylum seekers, the predictor does not significantly contribute to the explanation of the perception of the immigrant workers. The results indicate that Serbs express more positive attitudes towards asylum seekers than Croats. This could be due to the fact that Serbs in Croatia have the specific political and social status of a national minority, which perhaps makes them more open, inclined and empathetic to other minority groups. Similarly, investigating the attitudes towards refugees in different parts of Great Britain over the last 30 years, in the temporal and regional comparative perspective, Crawley, Drinkwater and Kauser (2013: 1) concluded that "characteristics such as belonging to an ethnic minority group or possessing a degree account for a large portion of the regional variations". However, since the respondents' declared ethnicity is significant only when it comes to predicting attitudes towards asylum seekers, and not immigrant workers, future research is needed in order to verify this interpretation.

According to the second set of hypotheses, different value orientations and political attitudes would have a significant effect on both dependent 
constructs, i.e. a negative perception of immigrant workers and asylum seekers was expected to be more pronounced in more conservative and authoritarian, less liberal, more closed towards the EU, more socially alienated respondents and respondents who have a lower interest in politics.

The results showed that conservativism has the strongest effect on both variables indicating that more conservative respondents perceive immigrant workers and asylum seekers more negatively. This finding corroborates the link between political conservativism and anti-immigration attitudes found in different research contexts (Chandler and Tsai, 2001; Semyonov, Raijman and Gorodzeisky, 2008). Additionally, the respondents with high scores on aggression and submission scales, those who support dominant-submissive authoritarianism and social dominance, respondents who are socially alienated, who have greater interest in politics and who support less socially oriented values, have more negative attitudes towards both groups. Most of these findings are consistent with other research. For example, in a metaanalysis of 155 samples from 17 countries, Cohrs and Stelzl (2010: 687-688) found that right-wing authoritarianism and social dominance orientation present "powerful predictors of anti-immigrant attitudes across countries, different measurements, and diverse samples". Rustenbach (2010) tested eight different explanations for anti-immigrant attitudes in 21 European countries, including societal integration measured through interpersonal trust, which was the most powerful predictor of anti-immigrant attitudes at individual and regional levels. Even though we measured it differently, our finding that respondents who are socially alienated and who support less socially oriented values is consistent with the societal attachment explanation of anti-immigrant attitudes (Rustenbach, 2010). However, when it comes to "interest in politics", our finding does not support other research, which indicates there is a positive influence from the level of knowledge and information about immigrants on attitudes towards them (Strabac, Aalberg and Valenta, 2014; Rustenbach, 2010). Further research is needed in order to determine whether this finding can be attributed to the specificity of the sample, or to the context of the survey that was conducted two months after Croatia's joining of the EU, with greater media emphasis on potential immigration.

The established differences between the two models (the significant effect of liberalism on more positive perception of immigrant workers and significant negative effect of anti-EU orientation when it comes to perception of asylum seekers) indicate a somewhat expected effect, even though it would have been presumed that they would both be significant in pre- 
dicting both dependent constructs. Liberalism measured in this research referred mostly to support to left-wing political parties and giving preference to socialism over capitalism, so it has probably proven to be more significant in the context of economic attribution of immigrant workers, than within the "culturally-defined" context of the perception of asylum seekers. On the other hand, the asylum seekers are often not perceived as being a part of this common group ("our society"), possibly due to their pronounced ethnic, cultural and even racial characteristics frequently emphasised in the media, as opposed to traditional immigrant workers (coming from ex-Yugoslav states), who are perceived as more similar to Croatian citizens. Nevertheless, more Western-oriented respondents, who tend to approve of "Western values" and the role of the EU, express more positive attitudes towards asylum seekers, thus also expressing more liberal and cosmopolitan views on ethnic diversity.

Another explanation of differences in attitudes towards the two groups is related to the content of statements in the survey. While immigrant workers were assessed mostly within the cultural dimension, the perception of asylum seekers was estimated within the economic dimension, emphasising the threat to the taxpayers and a burden for the Croatian social welfare system. It is possible that such threat is understood more directly and that respondents relate to it more personally.

\section{CONCLUSIONS, LIMITATIONS AND RECOMENDATIONS}

The aim of this paper has been to explore the dimensions, determinants and differences in perceptions related to immigrant workers and asylum seekers in eastern Croatia. The survey was conducted in September 2013, shortly after Croatia's accession to the EU, and it targeted the population of the newly established border area of the EU (Osijek-Baranja and VukovarSrijem counties). The main results indicate a significant perception of immigrant workers within the cultural threat dimension, together with the expression of a considerable degree of social distance towards them. On the other hand, the asylum seekers were also perceived as a security and economic threat. Most of the research hypotheses were confirmed within the two analysed regression models, indicating similar determinants of attitudes towards and perceptions of both groups.

Among socio-demographic variables, a statistically significant effect on both dependent variables was had by education level, age and political orientation. Those results indicate that older, less educated and politically 
right-oriented respondents express more negative attitudes towards immigrant workers and asylum seekers. The second model analysed the effect of selected political attitudes and value orientations resulting in significant prediction of negative attitudes towards both groups by pronounced conservativism, support of aggression and submission, social-dominance, dominant submissive authoritarianism and social alienation, rejecting socially oriented values and expressing greater interest in politics. Differences in prediction of dependent variables indicated that the more liberal respondents had more positive attitudes towards immigrant workers, while Serbs (in comparison to Croats) and respondents rejecting anti-EU orientations had more positive perceptions of asylum seekers. While most of our results correspond to other relevant research findings, some more specific results indicate possible avenues for further research. For example, the results show that attitudes towards labour immigrants polarised the respondents to a greater extent, than attitudes towards asylum seekers in the period when the survey was conducted. While it was possible to assume that our respondents were familiar with the notion of immigrant workers, it is more questionable to which extent they were informed about asylum issues, or had had direct contact with asylum seekers. The fact that this research was conducted in the immediate aftermath of Croatia joining the EU, might well have affected ambiguous attitudes towards immigration and accepting newcomers.

Another significant aspect of this research concerns the result that respondents' declared ethnicity is significant only when it comes to predicting attitudes towards asylum seekers, and not immigrant workers. This can lead to speculation that respondents who have had a displacement experience in the war during the 1990s have more positive or more negative attitudes towards asylum seekers. Introducing displacement experience as a potential determinant of attitudes towards immigrant workers and asylum seekers would enable future comparisons of various dimensions and differences in attitudes, also among different ethnic groups, within and inbetween regions and counties and respecting other socio-demographic and contextual variances.

It is also important to mention some methodological limitations of the research. Even though the population sample was large enough to enable analysis and give some indications of attitudinal dimensions, determinants and differences, further research should include a national representative sample for more extensive and elaborated results. This kind of data would enable comparisons of different regional contexts and specific geographic 
settings (e.g. war-affected vs. non-affected, rural-urban, border vs. non-border counties, macro-centres vs. micro-local communities, etc.), as well as the generalisation of the results.

Another limitation of this research is the fact that two separate scales, which measured the attitudes towards immigrant workers and asylum seekers, consisted of items that focused on different dimensions. While the instrument for measuring attitudes towards immigrant workers indicates dimensions of cultural threats and of social distance, the instrument measuring attitudes towards asylum seekers contains items largely pointing to perception of economic and security threat. It is possible to assume that attitudes towards immigrant workers and asylum seekers share the same dimensional space, while acknowledging differences. For example, asylum seekers are often perceived as a health threat, which is not the case with immigrant workers. Therefore, convergence of two scales into unified measurement instruments could pose a challenge for future construction and validation of instruments.

Finally, the current "humanitarian crisis" brings possible changes in attitudinal structures and imposes additional research challenges. It is possible to expect a more nuanced perception of refugees as protection seekers, but also a more negative general attitude towards them, especially after recent events regarding the situation in the EU. Future research will have to acknowledge the current situation and arrival and passage of a large number of refugees (more than half a million in 2015). This might have an effect on possible changes in attitudes and radicalisation of public opinion, especially after the terrorist attacks in Paris, the EU policies of border closing, walls and razor-wires, the practices of profiling "genuine refugees" from "undeserving economic migrants", success of the extreme rightist political options in the elections in the EU, and overall restrictions on the rights of refugees, and securitisation of migration issues.

However, even if attitudes towards asylum seekers in the general population might become more negative during the humanitarian crisis, it might be noteworthy to explore whether these attitudes are becoming more positive in the local communities where the transit reception centres are located (both are in the eastern Slavonia counties). This might be expected for several reasons: the displacement experience of the eastern Slavonia population (thus possibly relating more empathetically with asylum seekers and refugees), perceived economic benefits for local communities in the form of temporary employment within transit reception centres, and the transit character of refugees who for the most part continue their journey further 
towards Western or Northern EU countries. Although this research was conducted before the humanitarian crisis in Croatia, these results could provide specific starting-points for further research on this subject.

\section{REFERENCES}

Altemeyer, B. (2006). The Authoritarians. Winnipeg: University of Manitoba.

Banovac, B. and Boneta, Ž. (2006). Etnička distanca i socijalna (dez)integracija lokalnih zajednica, Revija za sociologiju, 37 (1-2): 21-46.

Barberić, J. (2015). Asylum in the Republic of Croatia one year after accession to the European Union. Zagreb: UNHCR (New Issues in Refugee Research, Research Paper, 273), http://www.unhcr.org/54dca6ee9.pdf (15 December 2015).

Bardy, A. and Schwartz, S. H. (2003). Values and Behavior: Strength and Structure Relations, Personality and Social Psychological Bulletin, 29 (10): 1207-1220, doi: $10.1177 / 0146167203254602$.

Baričević, V. (2013). Europske integracije i usvajanje europskih politika azilne zaštite u Hrvatskoj: prava osoba pod zaštitom i njihova integracija u društvo, in: D. ŽuparićIljić (ed.). Proih deset godina razvoja sustava azila u Hrvatskoj (s osvrtom na sustave azila u regiji). Zagreb: IMIN - Centar za mirovne studije - Kuća ljudskih prava, 99-130.

Chandler, C. R. and Tsai, Y. (2001). Social factors influencing immigration attitudes: an analysis of data from the General Social Survey, Social Science Journal, 38 (2): 177-188, doi: 10.1016/s0362-3319(01)00106-9.

Cohrs, C. J. and Stelzl, M. (2010). How Ideological Attitudes Predict Host Society Members' Attitudes toward Immigrants: Exploring Cross-National Differences, Journal of Social Issues, 66 (4): 673-694, doi: 10.1111/j.1540-4560.2010.01670.x.

Crawley, H., Drinkwater, S. and Kauser, R. (2013). Regional Variations in Attitudes towards Refugees: Evidence from Great Britain. Bonn: Institute for the Study of Labor (Discussion Paper, 7647), http://ftp.iza.org/dp7647.pdf (12 December 2015).

Čačić-Kumpes, J., Gregurović, S. and Kumpes, J. (2012). Migracija, integracija i stavovi prema imigrantima u Hrvatskoj, Revija za sociologiju, 42 (3): 305-336, doi: 10.5613/ rzs.42.3.3.

Čačić-Kumpes, J., Gregurović, M. and Kumpes, J. (2014). Generacijske razlike u odnosu prema etničkoj različitosti: stavovi hrvatskih srednjoškolaca i njihovih roditelja, Revija za sociologiju, 44 (3): 235-285, doi: 10.5613/rzs.44.3.2.

Čulig, B. (2005). Analiza procjene aktualnih društvenih i političkih problema u Hrvatskoj, Socijalna ekologija, 14 (3): 217-234.

Ervasti, H. (2004). Attitudes towards foreign-born settlers: Finland in a comparative perspective, Yearbook of Population Research in Finland, 40, 25-44.

Espenshade, T. J. and Hempstead, K. (1996). Contemporary American Attitudes Toward U.S. Immigration, International Migration Review, 30 (2): 535-570, doi: 10.2307/2547393.

Franc, R., Šakić, V. and Kaliterna-Lipovčan, Lj. (2010). Percipirane posljedice doseljavanja i stav prema doseljavanju, Društvena istraživanja, 19 (3): 421-440. 
Hair, J. F., Black, W. C., Babin, B. J. and Anderson, R. E. (2010). Multivariate Data Analysis. $7^{\text {th }}$ ed. New Jersey: Prentice Hall.

Halperin, E., Canetti-Nissim, D. and Pedahzur, A. (2007). Threatened by the uncontrollable: Psychological and socio-economic antecedents of social distance towards labor migrants in Israel, International Journal of Intercultural Relations, 31 (4): 459-478, doi: 10.1016/j.ijintrel.2007.01.003.

Hello, E., Scheepers, P. and Gijberts, M. (2002). Education and Ethnic Prejudice in Europe: explanations for crossnational variances in the educational effect on ethnic prejudice, Scandinavian Journal of Educational Research, 46 (1): 5-24, doi: 10.1080/00313830120115589.

Gregurović, M. (2014). Sociološki aspekti etničkih predrasuda na primjeru Hrvatske (PhD thesis). Zagreb: University of Zagreb, Faculty of Humanities and Social Sciences.

Kuti, S. (2014). Integration Policies: Country Report for Croatia. Florence: European University Institute - Migration Policy Centre (INTERACT Research Report 2014/13), http://cadmus.eui.eu/bitstream/handle/1814/32655/INTERACT-RR-2014\%20-\%2013. pdf (20 December 2015).

Markaki, Y. and Longhi, S. (2013). What determines attitudes to immigration in European countries? An analysis at the regional level, Migration Studies, 1 (3): 311337, doi:10.1093/migration/mnt015.

Mayda, A. M. (2004). Who Is Against Immigration?: A Cross-Country Investigation of Individual Attitudes toward Immigrants. Bonn: IZA (IZA Discussion paper series, 1115), http://www.econstor.eu/bitstream/10419/20350/1/dp1115.pdf (15 March 2016).

Mehrabian, A. (1996). Relations among Political Attitudes, Personality, and Psychopathology Assessed with New Measures of Libertarianism and Conservatism, Basic and Applied Social Psychology, 18 (4): 469-491, doi: 10.1207/s15324834basp1804_7.

Meuleman, B., Davidov, E. and Billiet, J. (2009). Changing attitudes toward immigration in Europe, 2002-2007: A dynamic group conflict theory approach, Social Science Research, 38 (2), 352-365, doi:10.1016/j.ssresearch.2008.09.006.

Mesić, M. and Bagić, D. (2011). Minority Return to Croatia - Study of an Open Process. Zagreb: UNHCR Croatia, http://www.unhcr.hr/images/stories/pdf/minority_ return_en.pdf (15 March 2016).

Mežnarić, S. (2014). Novi analitički elementi u promišljanju migracija, in: V. Puljiz, J. Tica and D. Vidović (eds). Migracije i razvoj Hrvatske: podloga za hrvatsku migracijsku strategiju. Zagreb: Hrvatska gospodarska komora, 179-199.

Murray, K. E. and Marx, D. M. (2013). Attitudes toward Unauthorized Immigrants, Authorized Immigrants, and Refugees, Cultural Diversity and Ethnic Minority Psychology, 19 (3): 332-341, doi: 10.1037/a0030812.

Nonchev, A., Encheva, S. and Atanassov, A. (2012). Social Inequalities and Variations in Tolerance toward Immigrants The Case of Bulgaria in the European Perspective, International Journal of Sociology, 42 (3): 77-103, doi: 10.2753/IJS0020-7659420304.

Pardos-Prado S. (2011). Framing Attitudes towards Immigrants in Europe: When Competition Does Not Matter, Journal of Ethnic and Migration Studies, 37 (7): 9991015, doi: 10.1080/1369183x.2011.572421.

Pratto, F., Sidanius, J., Stallworth, L. M. and Malle, B. F. (1994). Social Dominance Orientation: A Personality Variable Predicting Social and Political Attitudes, Journal of Personality and Social Psychology, 67 (4): 741-763, doi: 10.1037//0022-3514.67.4.741. 
Raijman, R. (2010). Citizenship Status, Ethno-National Origin and Entitlement to Rights: Majority Attitudes towards Minorities and Immigrants in Israel, Journal of Ethnic and Migration Studies, 36 (1): 87-106, doi: 10.1080/13691830903123245.

Rustenbach E. (2010). Sources of Negative Attitudes toward Immigrants in Europe: A Multi-Level Analysis, International Migration Review, 44 (1): 53-77, doi: 10.1111/j.17477379.2009.00798.x.

Scheepers, P., Gijsberts, M. and Coenders, M. (2002). Ethnic Exclusionism in European Countries. Public Opposition to Civil Rights for Legal Migrants as a Response to Perceived Ethnic Threat, European Sociological Review, 18 (1): 17-34, doi: 10.1093/ esr/18.1.17.

Schneider S. L. (2008). Anti-Immigrant Attitudes in Europe: Outgroup Size and Perceived Ethnic Threat, European Sociological Review, 24 (1): 53-67, doi:10.1093/esr/jcm034.

Semyonov, M., Raijman, R. and Gorodzeisky, A. (2006). The rise of antiforeigner sentiment in European societies, 1988-2000, American Sociological Review, 71 (3): 426449, doi:10.1177/000312240607100304.

Semyonov, M., Raijman, R. and Gorodzeisky, A. (2008). Foreigners' Impact on European Societies: Public Views and Perceptions in a Cross-National Comparative Perspective, International Journal of Comparative Sociology, 49 (1): 5-29, doi: $10.1177 / 0020715207088585$.

Strabac, Z., Aalberg, T. and Valenta, M. (2014). Attitudes towards Muslim Immigrants: Evidence from Survey Experiments across Four Countries, Journal of Ethnic and Migration Studies, 40 (1): 100-118, doi: 10.1080/1369183x.2013.831542.

Šram, Z. (2001). Antizapadna orijentacija kao komponenta šire ideologijske matrice: slučaj Vojvodine, Političkao misao, 38 (2): 91-110.

Šram, Z. (2009). Socijalna alijenacija bunjevačkih Hrvata u Vojvodini, Sociologija i prostor, 47 (1): 3-25.

Šram, Z. (2010). Etnocentrizam, percepcija prijetnje i hrvatski nacionalni identitet, Migracijske i etničke teme, 26 (2): 113-142.

Valenta, M., Zuparic-Iljic, D. and Vidovic, T. (2015). The Reluctant Asylum-Seekers: Migrants at the Southeastern Frontiers of the European Migration System, Refugee Survey Quarterly, 34 (3): 95-113, doi: 10.1093/rsq/hdv009.

Zavratnik, S. (2012). Images of Immigrants in Slovenia: Insights from Public Opinion, Ethnicity Studies / Etniskumo Studijos, 1-2: 204-223.

Zick, A., Pettigrew, T. F. and Wagner, U. (2008). Ethnic Prejudice and Discrimination in Europe, Journal of Social Issues, 64 (2): 233-251, doi: 10.1111/j.1540-4560.2008.00559.x .

Župarić-Iljić, D. and Gregurović, M. (2013). Stavovi studenata prema tražiteljima azila u Republici Hrvatskoj, Društvena istraživanja, 22 (1): 41-62, doi: 10.5559/di.22.1.03.

\section{SOURCES}

Census of Population, Households and Dwellings 2011, Croatian Bureau of Statistics, Zagreb, 2013, www.dzs.hr.

Migration of Population of Republic of Croatia, 2014, First Release 7.1.2., Croatian Bureau of Statistics, Zagreb, 2015, www.dzs.hr. 
Obavijesti o prihvatu i smještaju migranata u RH, Ministry of Interior of the Republic of Croatia, www.mup.hr.

Public Opinion in the European Union: First Results, Standard Eurobarometer 83, Spring 2015, http://ec.europa.eu/public_opinion/archives/eb/eb83/eb83_first_en.pdf

Statistical Yearbook of the Republic of Croatia 2014, Croatian Bureau of Statistics, Zagreb, 2014, www.dzs.hr.

Statistika, Ministry of Interior of the Republic of Croatia, www.mup.hr.

Statistike, UNHCR, 2015, www.unhcr.hr.

Zastupljenost $i$ indikatori diskriminacijskih i ksenofobičnih stavova u Republici Hrvatskoj istraživački izvještaj, Centar za mirovne studije, Zagreb, 2013, www.cms.hr. 


\title{
Stavovi prema migrantskim radnicima i tražiteljima azila u istočnoj Slavoniji: dimenzije, odrednice i razlike
}

\author{
Margareta Gregurović, Simona Kuti, Drago Župarić-lljić
}

\begin{abstract}
SAŽETAK
Ulazak Hrvatske u EU donio je nove istraživačke izazove i probleme u području istraživanja migracijskih tokova i trendova te $u$ području istraživanja stavova i percepcija stvarnih i mogućih imigranata. Cilj je ovoga rada istražiti stavove stanovnika dviju hrvatskih najistočnijih županija prema dvjema kategorijama imigranata: migrantskim radnicima i tražiteljima azila. Istraživanje je provedeno ubrzo nakon priključivanja Hrvatske EU-u, u rujnu 2013., a prikazani podaci dio su većeg istraživanja različitih aspekata migracijske i etničke problematike. Primjenom metode ankete istraživanje je provedeno na prigodnom uzorku od 1100 odraslih ispitanika iz dvije županije: Osječko-baranjske i Vukovarsko-srijemske. Podaci su analizirani nizom multivarijatnih statističkih procedura. Dobiveni rezultati pokazuju izraženu percepciju migrantskih radnika u okviru dimenzije kulturne prijetnje uz izražen značajan stupanj društvene distance. Nadalje, tražitelji azila doživljavaju se kao sigurnosna i ekonomska prijetnja. Dva analizirana regresijska modela pokazuju prilično ujednačene učinke prediktorskih varijabli na percepciju migrantskih radnika i tražitelja azila. U okviru analize učinka sociodemografskih karakteristika ispitanika značajan učinak na obje zavisne varijable imale su dob i politička orijentacija, pri čemu su stariji i politički desno orijentirani ispitanici izražavali negativnije stavove prema objema skupinama. Od ostalih sociodemografskih varijabli obrazovanje ispitanika imalo je značajan učinak na percepciju migrantskih radnika, a etničnost ispitanika na percepciju tražitelja azila. U drugom se modelu analizirao učinak odabranih političkih stavova i vrijednosnih orijentacija, pri čemu rezultati pokazuju da ispitanici koji su skloniji konzervativizmu, koji podržavaju agresiju i submisiju, društvenu dominaciju, autoritarnost i društvenu alijenaciju, ispitanici koji odbacuju društveno orijentirane vrijednosti te izražavaju veći interes za politiku statistički značajno više izražavaju negativne stavove prema objema skupinama. Razlike u predikciji dviju zavisnih varijabli pokazuju da liberalniji i obrazovaniji ispitanici iskazuju pozitivnije stavove prema migrantskim radnicima, a Srbi (u odnosu na Hrvate) i ispitanici koji odbacuju anti-EU orijentaciju pozitivnije stavove prema tražiteljima azila. Dobiveni rezultati uspoređuju se s drugim relevantnim istraživanjima, pri čemu se raspravlja o opaženim razlikama i sličnostima te se daju preporuke za daljnja istraživanja.
\end{abstract}

KLJUČNE RIJEČI: migrantski radnici, tražitelji azila, imigracija, stavovi, istočna Hrvatska 